\title{
Un nuevo descubrimiento quijotesco: los dibujos anónimos para la edición ilustrada del 'Quijote' impresa en Amberes, 1672-1673 (BNMadrid: Dib/16/51/1-34)
}

\author{
José Manuel Lucía Megías*
}

1. La Biblioteca Nacional de Madrid conserva el juego de dibujos originales para la edición del Quijote, impresa en Amberes entre 1672 y 1673 por Jerónimo y Juan Bautista Verdussen. Uno de los escasos juegos de dibujos originales que conservamos de las primeras ediciones ilustradas de la obra cervantina, por no decir el único ${ }^{1}$. Desde 1956 han estado en los fondos de la Sala Goya, pero, al no haber sido catalogados, habían permanecido inéditos y desconocidos para los especialistas. Una investigación paralela, que todavía no ha dado sus frutos (la localización del ejemplar de Les Adventures de fameux chevalier Dom Quixot de la Manche et de Sancho Panza, son escuyer (París, h. 1650), que había servido de original para la edición facsímil con que se había conmemorado la Exposición Universal e Internacional, celebrada en Bruselas en 1958), me llevó a descubrirlos el año pasado. En las notas previas al citado facsímil, el entonces Jefe de Servicio Nacional de Información Bibliográfica, Justo García Morales, contaba los detalles de una subasta que se había celebrado en París el 5 de diciembre de 1956, a la que había asistido acompañando a José López de Toro, subdirector de la Biblioteca Nacional. El catálogo de la subasta Don Quichotte de la Manche. Editions en diverses langues de 1605 á 1923... no podía ser más atractivo, y entre las joyas que

* Universidad Complutense de Madrid - Centro de Estudios Cervantinos.

1. En la Hispanic Society of America se conservan 23 dibujos originales atribuidos a Jerôme David de las primeras estampas sueltas conocidas con tema quijotesco, que se imprimieron en París a mediados del siglo XVII. Algunas de ellas, en blanco y negro, pueden consultarse en Patrick LENGHAN, Imágenes del Quijote, Madrid, 2003; se reproducen todos por primera vez en Lucía MEGías, José Manuel y Lenaghan, Patrick, Facsímil de Les Adventures de fameux chevalier Dom Quixot de la Manche et de Sancho Panza, son escuyer, Toledo, Sociedad Quijote 2005, 2005. 
así se presentaban una sobresalía por encima de muchas otra: un ejemplar del primer juego de estampas sueltas del Quijote, casi todas ellas ideadas por el pintor Jerôme David e impresas por Lagniet a mediados del siglo XVII. Sólo se conocía un juego en la Hispanic Society of New York y otro en la Bibliothèque Nationale de Francia, al que habría que añadir el de la familia Foronda, fuente del facsímil ${ }^{2}$. Pero no pudo ser: el librero Berés, de las Galerías Frietland, se lo adjudicó por la nada desdeñable cifra de 1.212 .000 francos. Pero no todo estaba perdido, tal y como Justo García Morales indica en las notas iniciales al facsímil de 1958:

Sólo compensó nuestro disgusto la compra de otros dibujos notibilísimos: los 34 grabados de F. Boutttats, en tinta china, que acompañan a la primera edición ilustrada en lengua española; precisamente la de Bruselas, Mommaerte, 1662 y 1671, que como puede apreciarse, son casi contemporáneos de los de Lagniet (p. 12).

En la actualidad, los 34 dibujos originales, en pluma, tinta china y aguada, tienen la signatura: Dib/16/51/1-Dib/16/51/34 en la Sala Goya de la Biblioteca Nacional de Madrid.

2. No iba descaminado Justo García Morales en su apreciación de "dibujos notabilísimos", por lo que tienen de únicos -mucho más que las piezas impresas por Lagniet-, pero también, por ser la clave que nos ha permitido plantear una nueva hipótesis sobre la relación de las primeras ediciones ilustradas del Quijote, que conforman lo que he venido llamando modelo iconográfico holandés $^{3}$, ya que, a pesar de lo que se ha pensado hasta el momento -y como se sigue sosteniendo desde el catálogo Ariadna de la Biblioteca Nacional- no creo que estos dibujos sean obra de Frederick Bouttats (o no al menos, necesariamente) ni que se hayan de situar con anterioridad a 1662, fecha en la que aparece la primera edición ilustrada del Quijote en español. Este juego de dibujos, al contrario, han de ser tenidos (seguramente) como anónimos y fueron realizados para servir de base a la edición de Amberes de 1672 y 1673, que es la primera que va a incorporar estampas grabadas por Frederik Bouttatas, convirtiéndose en la que determina finalmente, con sus 34 ilustraciones, el modelo iconográfico holandés, siendo éste -y no el de Dordrecht de 1657 con 26 estampas debidas a Jacob Savery- el que se difunda por Italia (Roma, 1677), Francia (París, 1681) y Alemania (Basel, Frankfurt, 1682).

2. En la actualidad se habla de un cuarto ejemplar, en una biblioteca privada de Caen; por su parte, en la sala de Subastas Claude Aguttes, el pasado 28 de abril de 2005 se subastó un nuevo juego de estampas - ¿quizás el de Caen?- que fue adjudicado a un prestigioso coleccionista español.

3. Sobre este asunto, pueden consultarse nuestros trabajos: "Modelos iconográficos de El Quijote (siglos XVII-XVIII): I. Primeras notas teóricas", Litterae, 2 (2002), pp. 59-103; "Los modelos iconográficos de El Quijote (siglos XVII-XVIII): II. De las primeras lecturas al modelo iconográfico holandés", Litterae, 3-4 (2003-2004), pp. 9-59 y Los primeros ilustradores del Quijote, Madrid, Ollero \& Ramos, 2005. 
3. Como ya he tenido ocasión de indicar en los trabajos anteriormente reseñados en nota 3, frente a lo que sucederá con otros modelos iconográficos -sólo hay que pensar en el inglés nacido del éxito de la edición de lujo del Quijote, impresa en Londres por los Tonson y auspiciada por Lord Carteret, en 1738-, el modelo iconográfico holandés va a nacer de una propuesta muy particular, la que realiza el impresor y grabador Jacob Savery con 26 estampas en su recién inaugurado taller de impresión en Dordrecht en 1657, que se va a difundir -con copias más o menos fidedignas, reduciendo en todas ellas su programa iconográfico- gracias a diferentes propuestas editoriales, que se concretan en las siguientes:

a) 1662 (Bruselas, Juan Mommaerte): 16 estampas + dos frontispicios ${ }^{4}$

b) 1665 (Orleáns y París, Gillet Hotot): 6 estampas + dos frontispicios

c) 1671 (Bruselas, a costa de Pedro de la Calle): 16 estampas + dos frontispicios

Pero sólo entre 1672 y 1673, cuando los Verdussen (Jerónimo y Juan Bautista) saquen a la luz una nueva edición ilustrada del Quijote con 32 estampas y los dos frontispicios, como se indica desde la propia portada (Nueva Edicion, coregida y ilustrada con 32, differentes Estampas muy donosas, y apropiadas á la materia), sólo entonces puede entenderse que se ha completado el programa del modelo iconográfico holandés. En esta última propuesta, además de Jacob Savery -el dibujante y grabador de las primeras estampas de 1657-, hará acto de presencia un nuevo nombre: Frederik Bouttats, pero a él sólo se le pueden atribuir aquellas estampas que aparecen con su firma; para el resto se reutilizan las mismas planchas que ya se habían utilizado para 1662 , y que los Verdussen seguramente poseían. Como se indica en la Suma del privilegio que imprimen Jerónimo y Juan Bautista Verdussen en su edición de la segunda parte del Quijote de 1672, el 5 de septiembre de 1669 se produjo el traspaso del privilegio de impresión con el que contaban los herederos de Juan Mommaerte a los citados impresores de Amberes. En el siguiente cuadro podrá apreciarse mejor la relación de estampas y su autoría en las tres ediciones ilustradas del Quijote que han ido conformando este modelo iconográfico: 1657,1662 y $1672-1673$ :

4. Dado que se trata de estampas finas, es decir, sueltas, y que el tamaño en $8^{\circ}$ es común a las ediciones del Quijote que se realizan en diferentes talleres europeos, no es extraño encontrar ejemplares extrailustrados -o grangerizados-, mezclándose estampas de diferentes ediciones: el ejemplar de la Real Academia Española de la edición de Bruselas de 1662 (R-101-R/102) es una buena prueba de ello. En el Centro de Estudios Cervantinos, por su parte, se conservan ejemplares de las primeras ediciones del Quijote, al que se les ha añadido algunas de estas estampas (puede verse reproducción en La imagen del Quijote en el mundo, Madrid/Barcelona, Lunwerg, 2004). 


\begin{tabular}{|c|c|c|c|}
\hline Episodio & 1657 & 1662 & $1672-1673$ \\
\hline 11. Frontispicio de la primera parte & 1 & 1 & 1 \\
\hline 12. Don Quijote es armado caballero & - & - & 2 (Bouttats) \\
\hline 13. Liberación del niño & 2 & - & 3 (Bouttats) \\
\hline 14. Don Quijote vuelve a su aldea & - & - & 4 (Boutttats) \\
\hline 15. Aventuras del vizcaíno y la de los Molinos de Viento & 3 & 2 & 5 \\
\hline 16. Aparición de Marcela y entierro de Crisóstomo & 4 & 3 & 6 \\
\hline 17. Trágico encuentro entre don Quijote y Maritornes & 5 & 4 & 7 \\
\hline 18. Manteamiento de Sancho Panza & 6 & 5 & 8 \\
\hline 19. Aventura del Cuerpo muerto & - & - & 9 (Bouttats) \\
\hline 10. Liberación de los galeotes & 7 & - & 10 (Bouttats) \\
\hline 11. Don Quijote es abatido por Cardenio en Sierra Morena & 8 & 6 & 11 \\
\hline 12. Penitencia en Sierra Morena & 9 & - & 12 (Bouttats) \\
\hline 13. Don Quijote se enfada y pega a Sancho Panza & 10 & 9 & 16 \\
\hline 14. Fernando y Luscinda se encuentran con Dorotea y Cardenio & o 11 & 8 & 14 \\
\hline 15. Engaño de Maritornes & 12 & -- & 15 (Bouttats) \\
\hline 16. Pelea en la venta (Aventura del Baciyelmo) & 13 & 7 & 13 \\
\hline 17. Aventura de los disciplinantes & - & - & 17 (Bouttats) \\
\hline 18. Frontispicio de la segunda parte. & 14 & 10 & 18 \\
\hline 19. Encuentro con Aldonza Lorenzo & 15 & - & 19 (Bouttats) \\
\hline 20. Aventura de la Carreta de "Las Cortes de la Muerte" & 16 & 11 & 20 \\
\hline 21. Victoria de Don Quijote sobre el Caballero del Bosque & - & - & 21 (Bouttats) \\
\hline 22. Aventura de los leones & 17 & 12 & 22 \\
\hline 23. Don Quijote a la entrada de la cueva de Montesinos & 18 & 13 & 23 \\
\hline 24. Don Quijote destruye el retablo de Maese Pedro & 19 & 14 & 24 \\
\hline 25. Aventura del Rebuzno & 20 & - & 25 (Bouttats) \\
\hline 26. Bromas a Sancho Panza en casa de los Duques & 21 & - & 26 (Bouttats) \\
\hline 27. Don Quijote ante el carro de Merlín & 22 & 15 & 27 \\
\hline 28. Aventura de Clavileño & 23 & 16 & 28 \\
\hline 29. Sancho Panza gobernador y juez & 24 & - & 29 (Bouttats) \\
\hline 30. La visita nocturna de la Dueña Rodríguez & - & - & 30 (Bouttats) \\
\hline 31. Final del gobierno de Sancho Panza en la Ínsula Barataria & 25 & 17 & 31 \\
\hline 32. Aventura de la Cabeza Encantada & - & - & 32 (Bouttats) \\
\hline 33. Don Quijote es vencido por el Caballero de la Blanca Luna & 26 & 18 & 33 \\
\hline 34. Encantamiento de Altisidora & - & - & 34 (Bouttats) \\
\hline
\end{tabular}

4. De las 34 estampas con que se ilustra la edición de Amberes de 1672 y 1673 , sólo 16 vendrán firmadas por F. Bouttats, y todas ellas comparten una doble característica: su originalidad y su mayor tamaño, lo que las distingue del resto. O son estampas que ilustran por primera vez un episodio del Quijo$t e^{5}$ o se ofrecen nuevos diseños a episodios e imágenes ilustradas en 1657, pero que se habían suprimido de 1662 , lo que muestra, una vez, la estrecha relación entre las dos ediciones ilustradas españolas.

En el juego de dibujos originales, todos ellos realizados por una misma mano en tamaño y características muy similares, encontramos tres posibilidades:

5. Y en concreto, son: [1] Don Quijote es armado caballero por Palomeque el Zurdo [I, III]; [2] Don Quijote vuelve a su aldea, después de su primera salida [I, v]; [3] Aventura del Cuerpo Muerto (los encamisados) [I, XIX]; [4] Aventura de los Disciplinantes [I, LII]; [5] Don Quijote vence al Caballero del Bosque [II, XIV]; [6] Visita nocturna de Doña Rodríguez a la habitación de don Quijote [II, XLVIII]; [7] Aventura de la Cabeza Encantada [II, LXII]; y [8] Encantamiento de Altisidora [II, LXIX] 
a) Copia de los diseños aparecidos en Bruselas, 1662

b) Dibujo original sobre un episodio ya ilustrado en Dordrecht, 1657, pero que no ha aparecido en 1662

c) Nuevas estampas, tanto en el diseño como en la elección del episodio.

Frederick Bouttats sólo realizará, ampliando sus detalles, los grabados de las 16 estampas que forman parte de los apartados b y c. Para los 18 restantes, se reutilizarán las planchas de 1662 . Teniendo en cuenta que el juego de dibujos es completo, quizás en un principio se pensó en un nuevo juego de estampas, grabadas todas ellas por F. Bouttats; pero, de ser así, el proyecto inicial nunca llegó a completarse: en 1672 y 1673, los Verdussen llevarán a cabo una mezcla de planchas existentes (Bruselas, 1662) y de nuevos diseños, que en su conjunto conformarán el modelo iconográfico holandés. Los grabadores que en otros talleres se acerquen a este programa iconográfico en los siguientes años (N. Cause en París, 1681 o François Diodati, Basel, 1682) unificarán ya tamaños y diseños.

En todo caso, el juego de dibujos originales conservados en la Biblioteca Nacional de Madrid muestra cómo se había concretado el programa del modelo iconográfico holandés, y la pericia como grabador de Frederick Bouttats, que llenó de detalles su modelo. Dado su carácter único, vale la pena reproducirlas todas en el orden del texto -y no de conservación en la Biblioteca Nacional de Madrid-, para así poder apreciar las raíces de uno de los modelos iconográficos más extendidos y permanentes de toda la amplia y rica historia editorial del Quijote $^{6}$.

6. Los dibujos originales de la Biblioteca Nacional de Madrid también pueden consultarse, vinculados a cada una de la estampas de la edición de Amberes, 1672-1673 en el proyecto Banco de imágenes del Quijote: 1605-1905 (QBI): http://www.qbi2005.org.; así como en el número especial de la Revista Poesía, Madrid, 2005. 


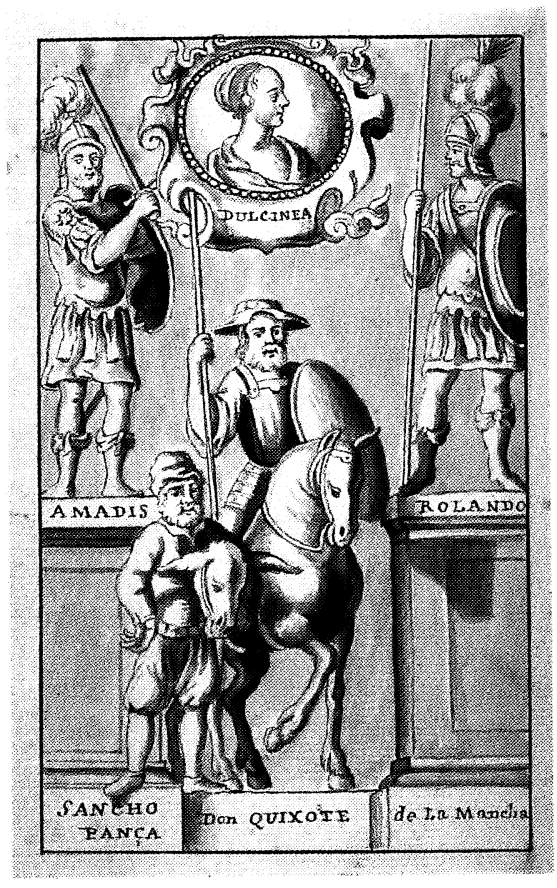

1. Frontispicio de la primera parte

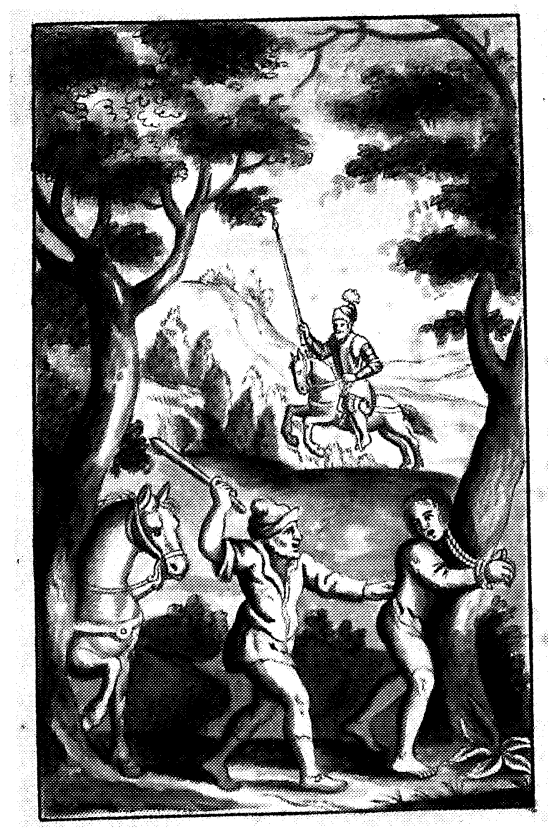

3. Primera aventura de don Quijote: el niño Andrés (I, cap. 3)

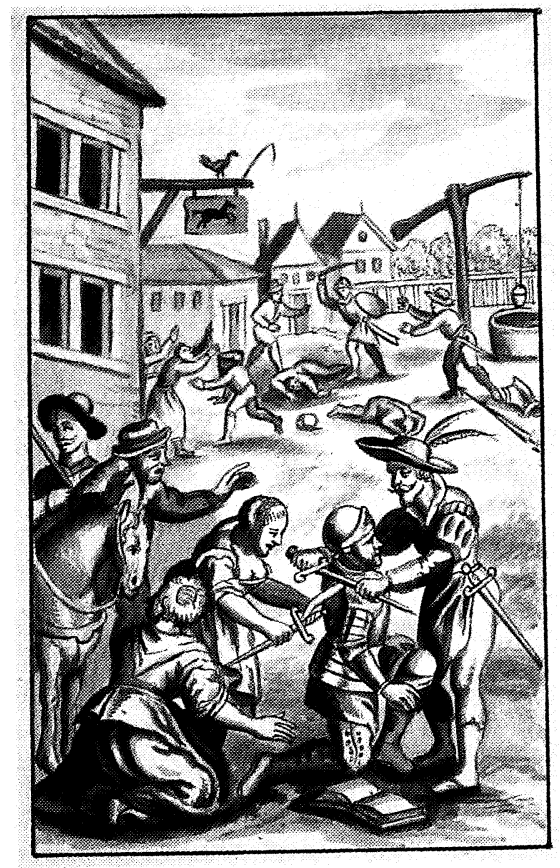

2. Don Quijote es armado caballero (I, cap. 3)

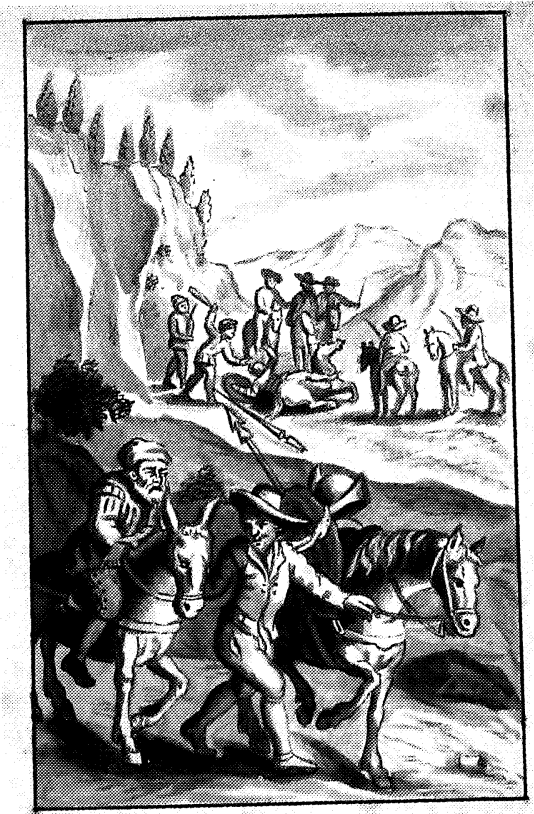

4. Aventura de los mercaderes (I, cap. 4) y vuelta de don Quijote a su lugar (I; cap. 5) 


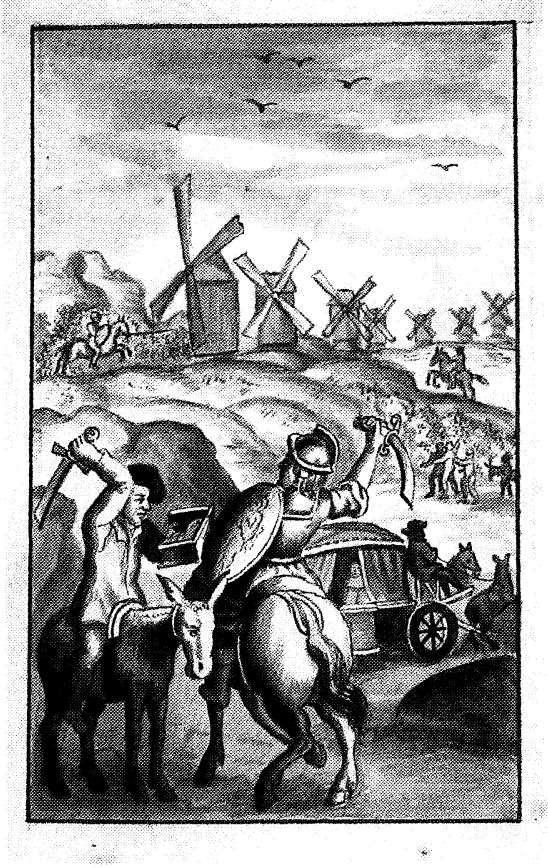

5. Aventura de los molinos de viento y combate contra el vizcaíno (I, cap. 8)

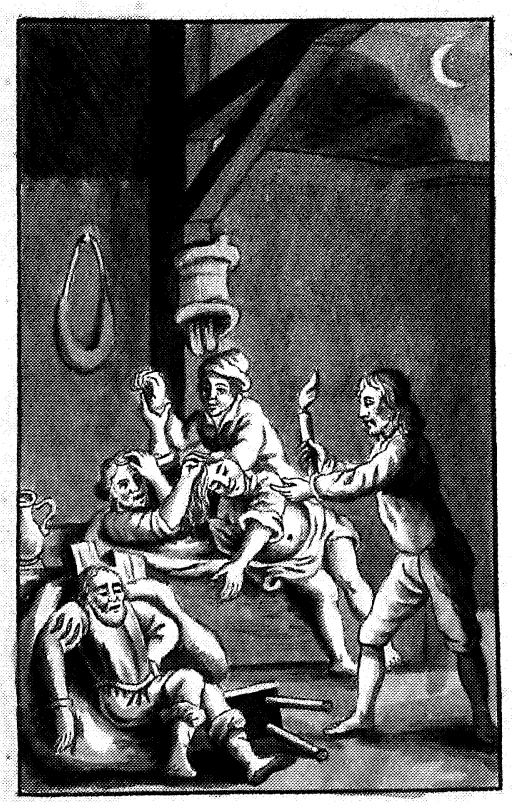

7. Encuentro nocturno con Maritornes (I, cap. 16)

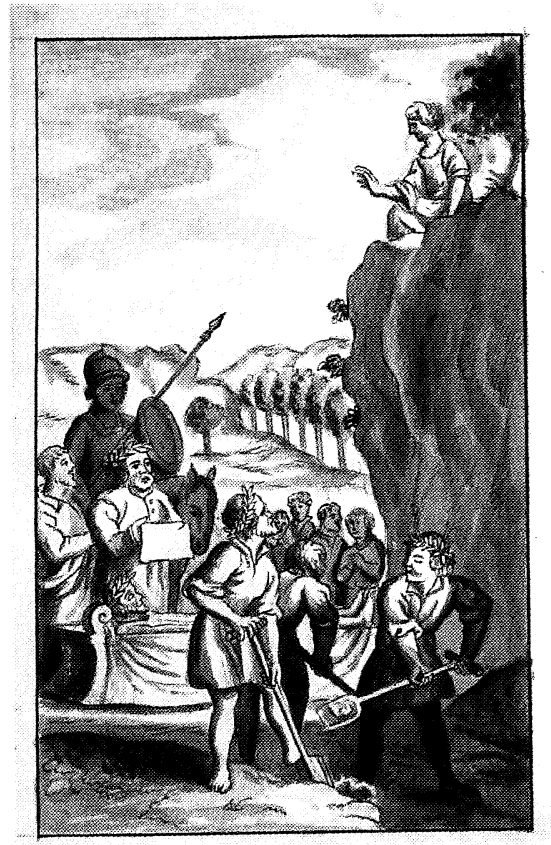

6. Entierro de Crisóstomo (I, cap. 14)

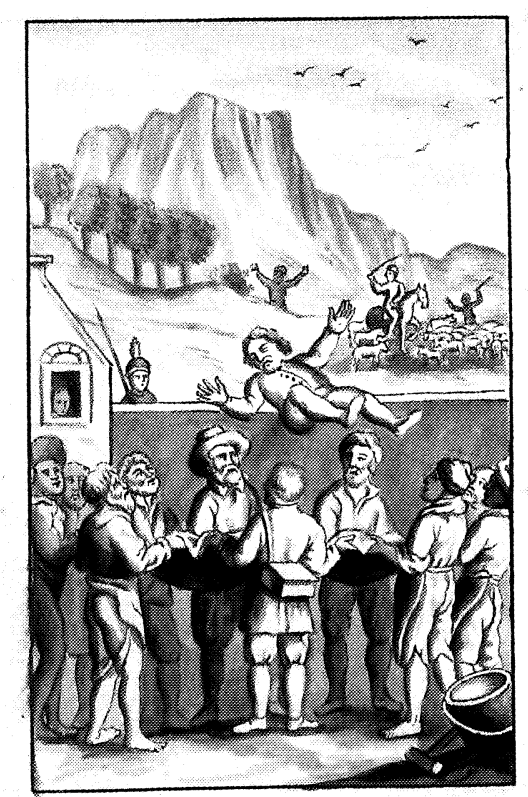

8. Manteamiento de Sancho Panza (I, cap. 17), y aventura de los carneros (I, cap. 18) 


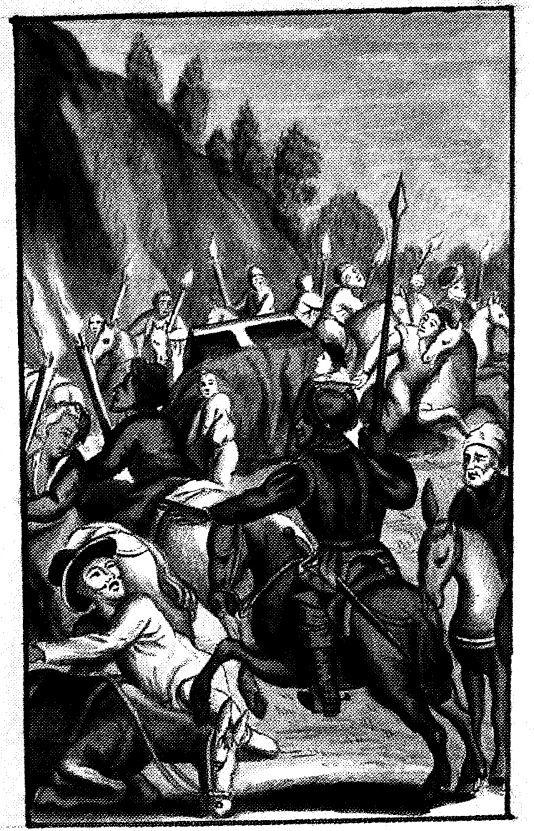

9. Aventura de los encamisados (I, cap. 19)

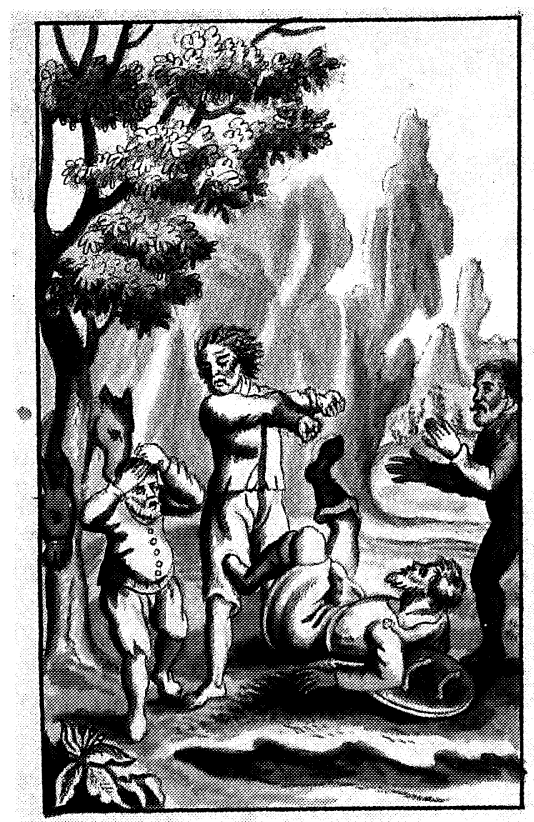

11. Ataque de locura de Cardenio (I, cap. 24)

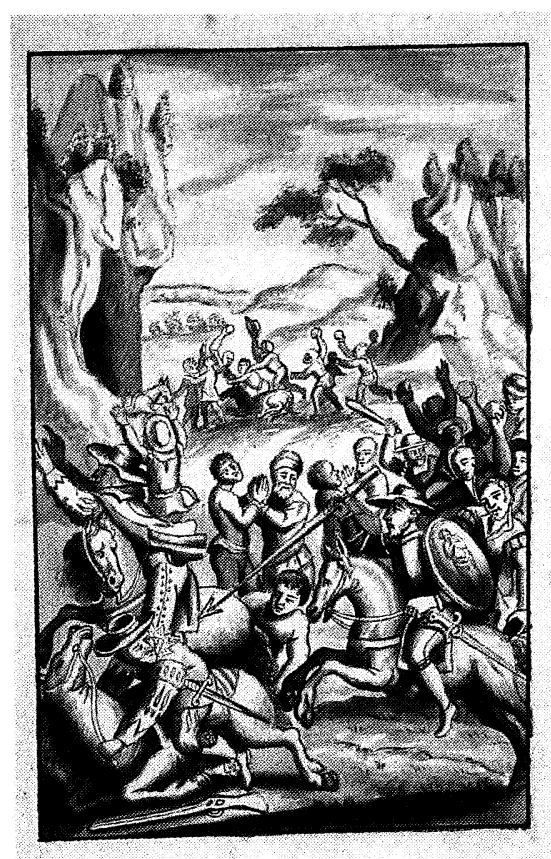

10. Aventura de los galeotes (I, cap. 22)

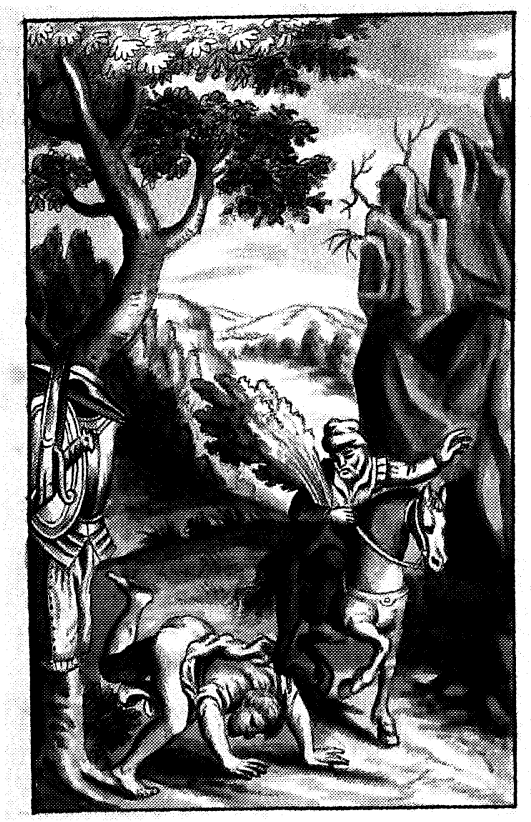

12. Penitencia de don Quijote en Sierra Morena (I, cap. 25) 


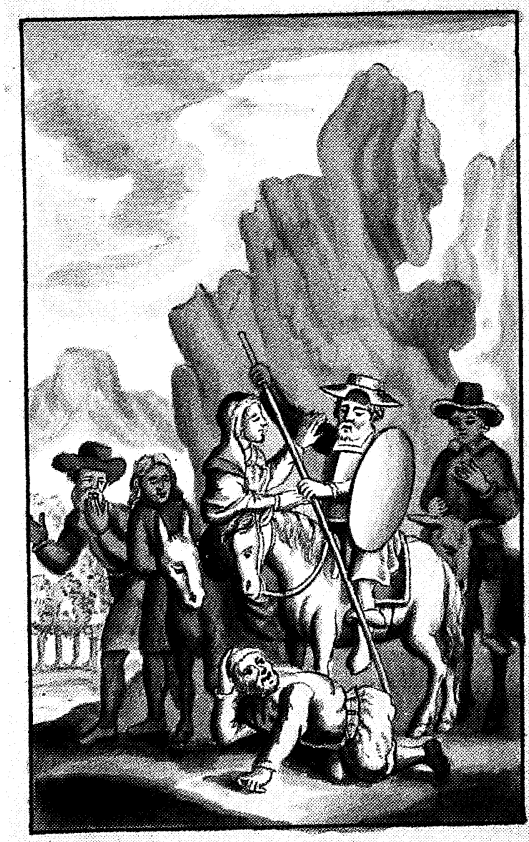

13. Don Quijote pega a Sancho Panza (I, 30)

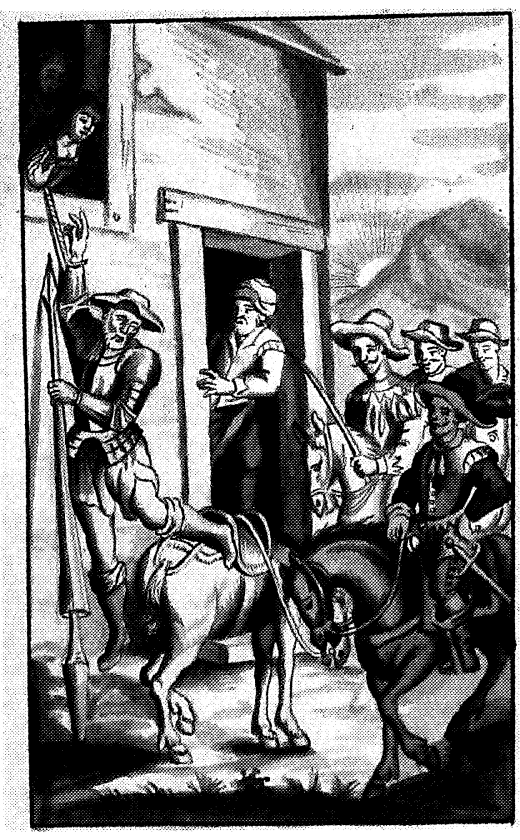

15. Don Quijote engañado, colgado de una ventana (I, cap. 43)

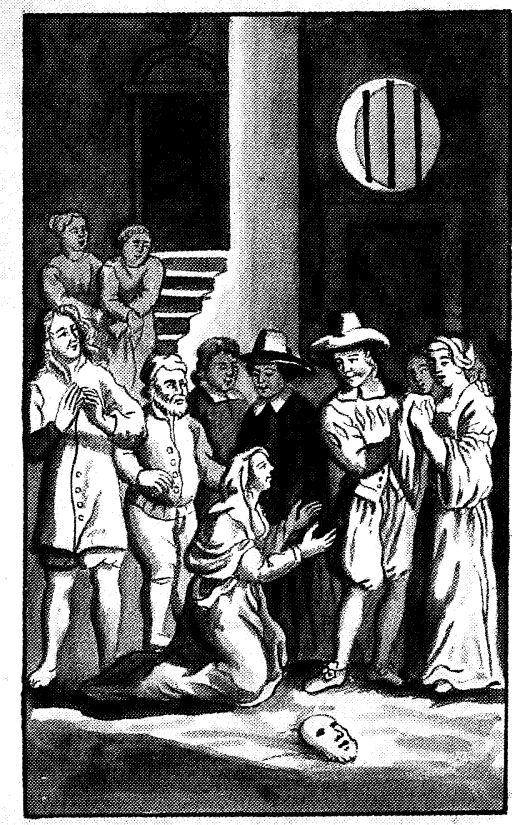

14. Encuentro en la venta (I, cap. 36)

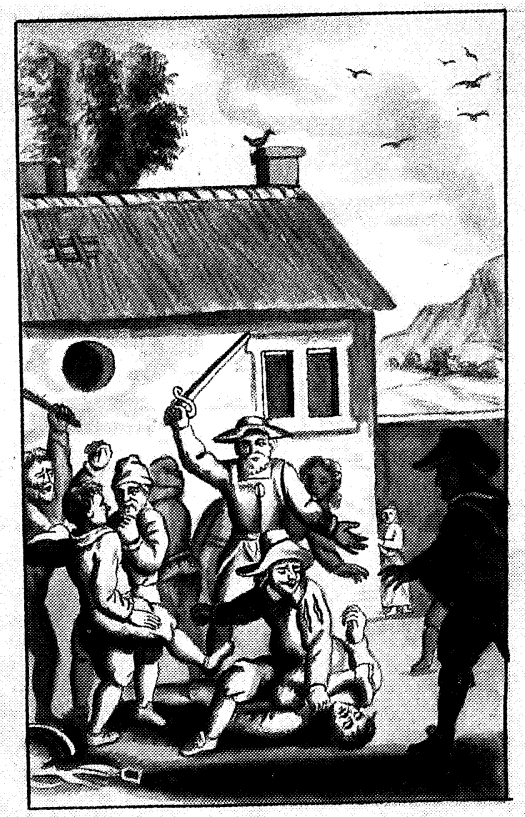

16. Aventura del baciyelmo (I, cap. 45) 


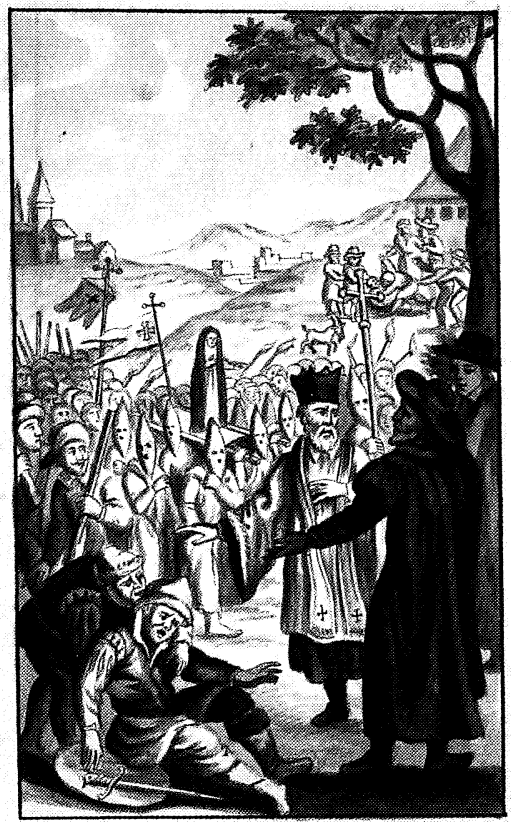

17. Disputa de don Quijote con el cabrero y Aventura de los disciplinantes (I, cap. 52)

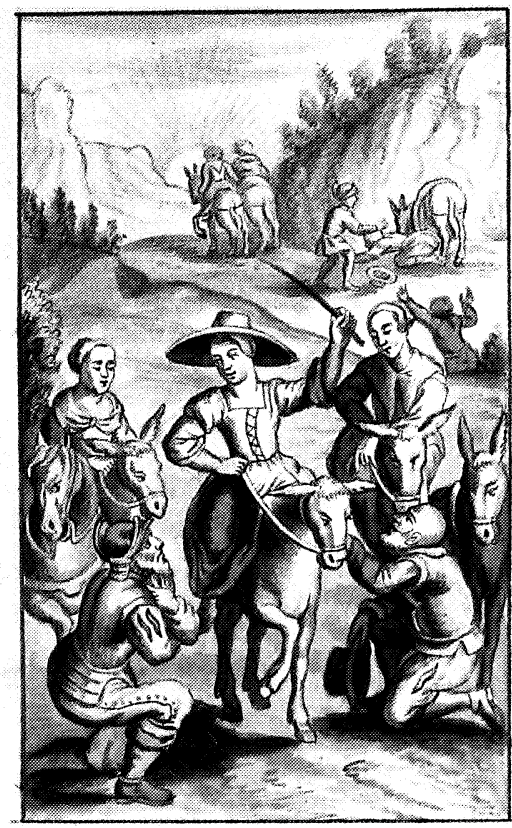

19. Don Quijote ante una encantada Dulcinea (II cap. 10)

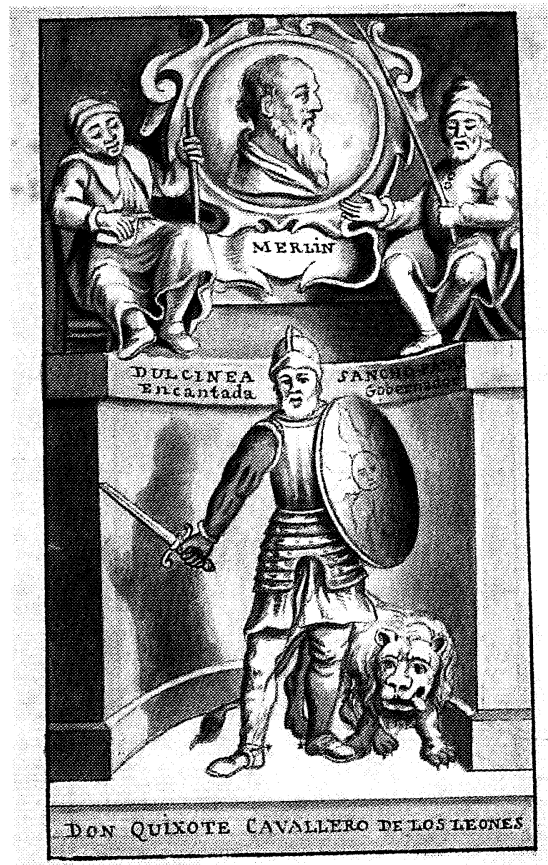

18. Frontispicio de la segunda parte

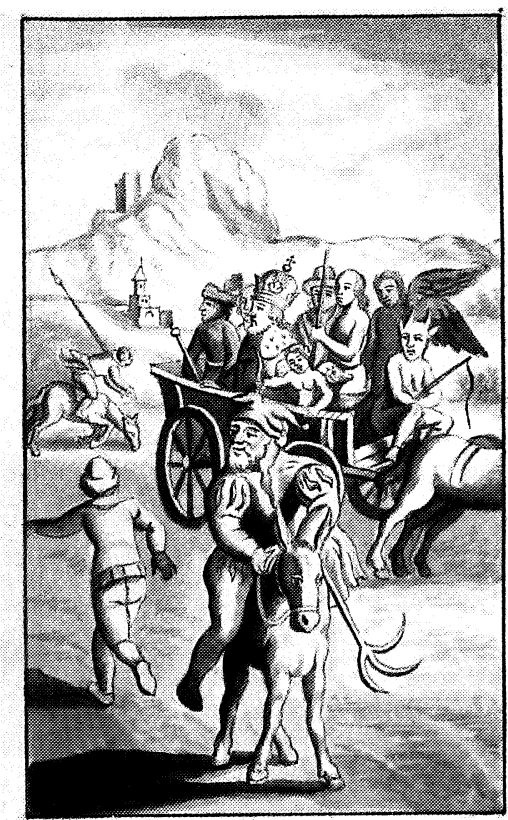

20. Don Quijote ante la carreta de las Cortes de la Muerte (II, cap. 11) 
UN NUEVO DESCUBRIMIENTO QUIJOTESCO: LOS DIBUJOS ANÓNIMOS PARA LA EDICIÓN ILUSTRADA... 137

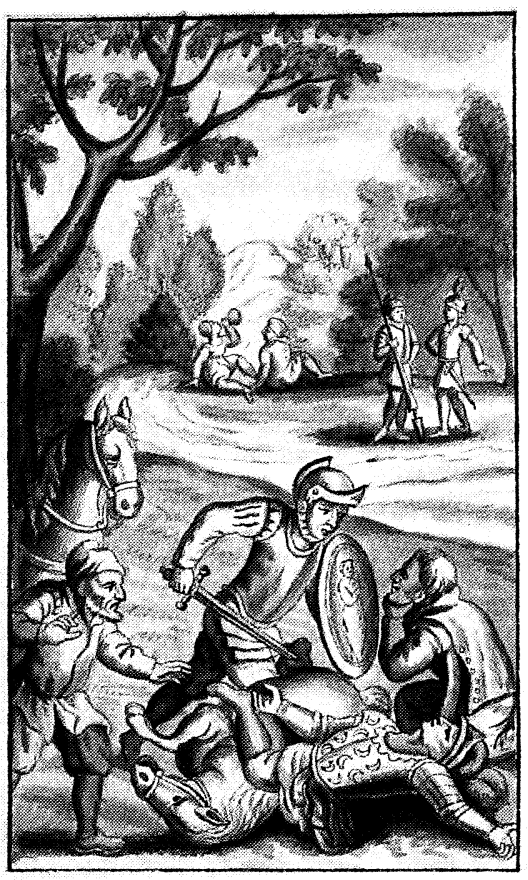

21. Don Quijote vence al Caballero del Bosque (II, cap. 14)

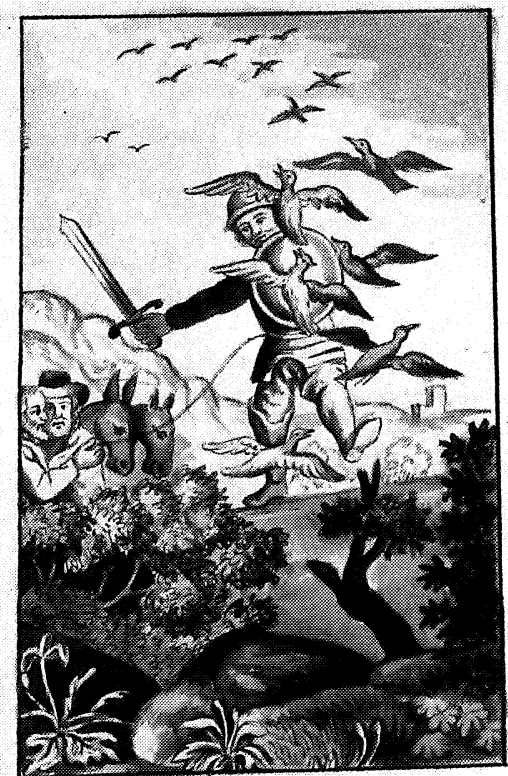

23. Don Quijote entra en la Cueva de Montesinos (II, cap. 22)

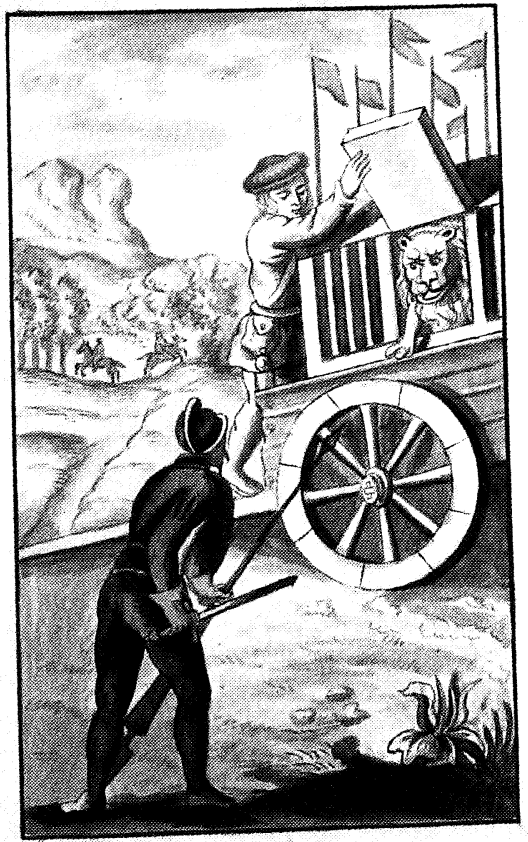

22. Aventura de los leones (II, cap. 17)

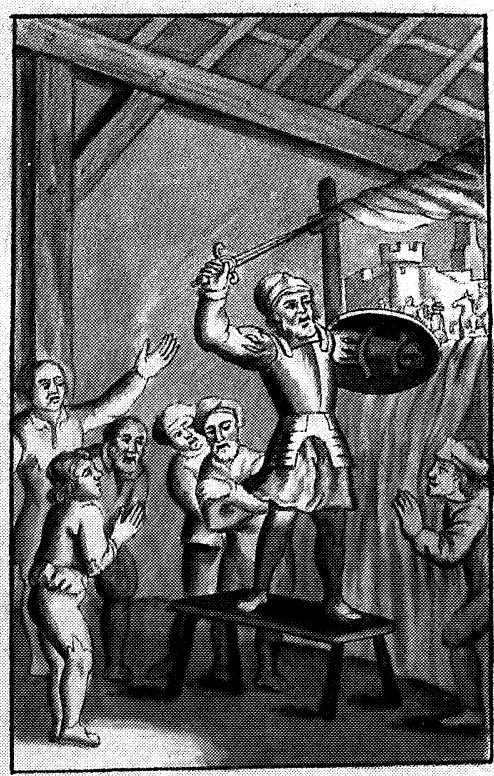

24. Aventura del Retablo de Maese Pedro (II, cap. 26) 


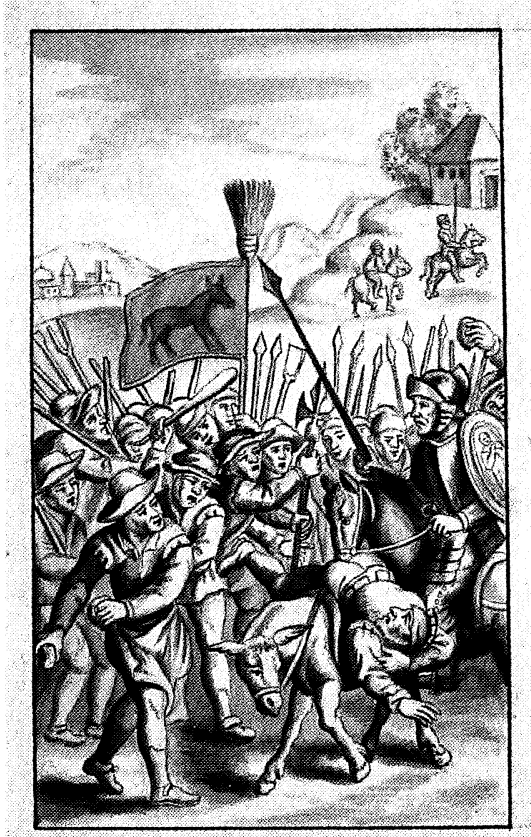

25. Aventura del rebuzno (II, cap. 27)

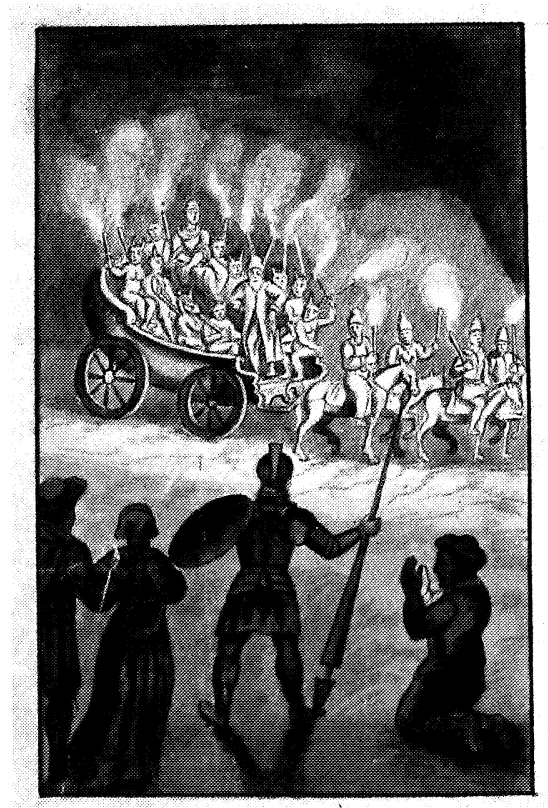

27. Llegada del carro de Merlín (II, cap. 35)

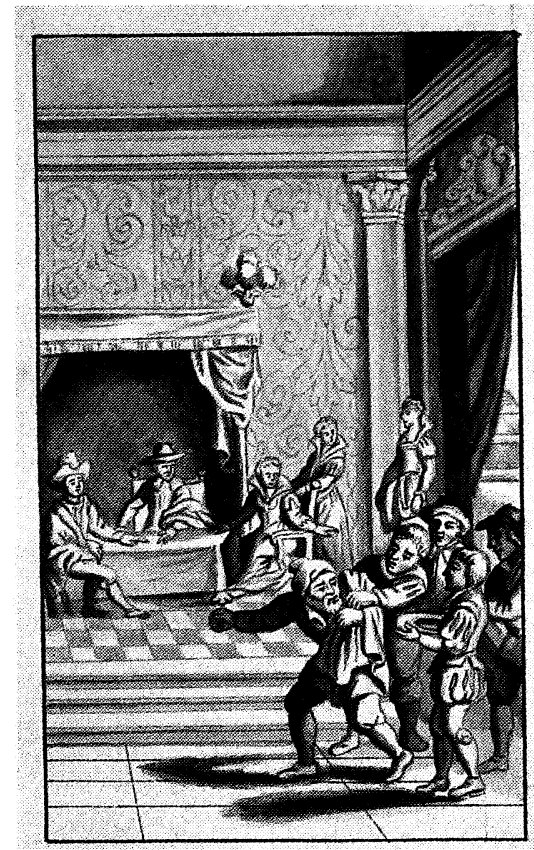

26. Bromas en casa de los Duques (II, cap. 32)

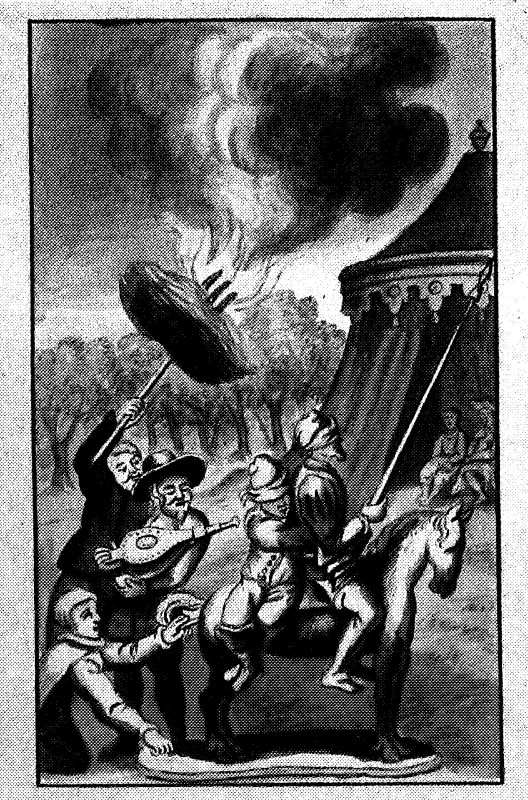

28. Aventura de Clavileño (II, cap. 42)

ANALES CERVANTINOS, VOL. XXXVII, PP. 127-140, 2005. ISSN: 0569-9878 
UN NUEVO DESCUBRIMIENTO QUIJOTESCO: LOS DIBUJOS ANÓNIMOS PARA LA EDICIÓN ILUSTRADA... 139

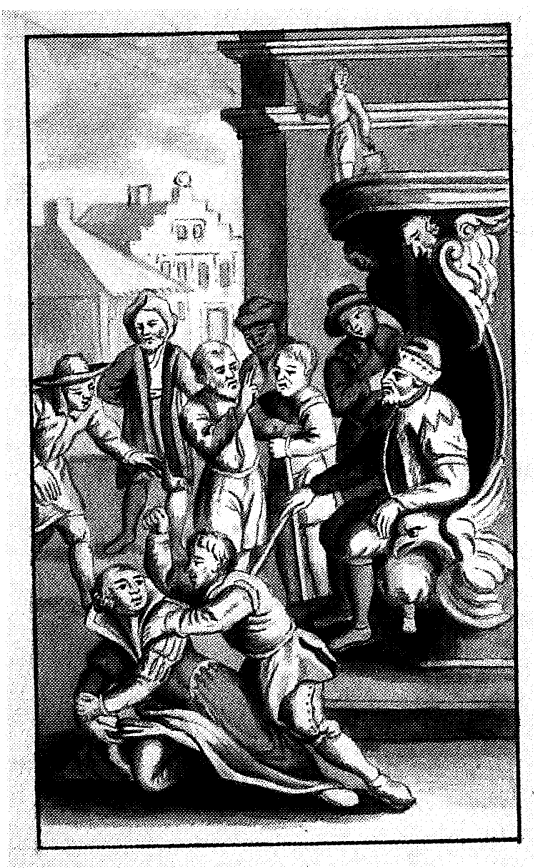

29. Sancho Panza, juez de la Ínsula Barataria (II, cap. 45)

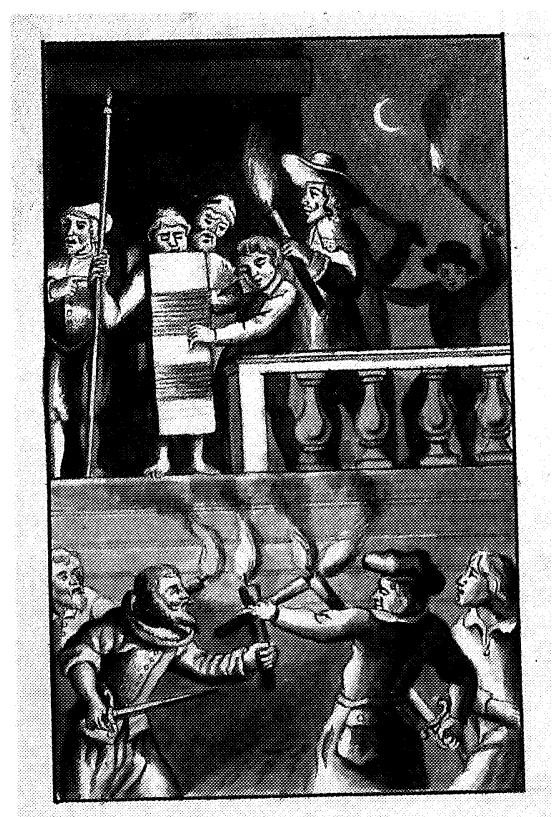

31. Final del gobierno de Sancho Panza (II, cap. 53)

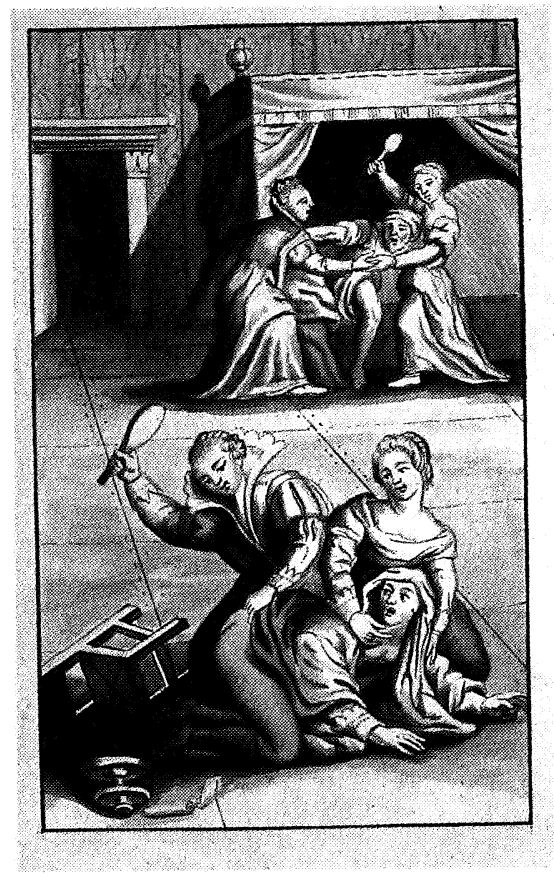

30. Doña Rodríguez y Don Quijote (II, cap. 48)

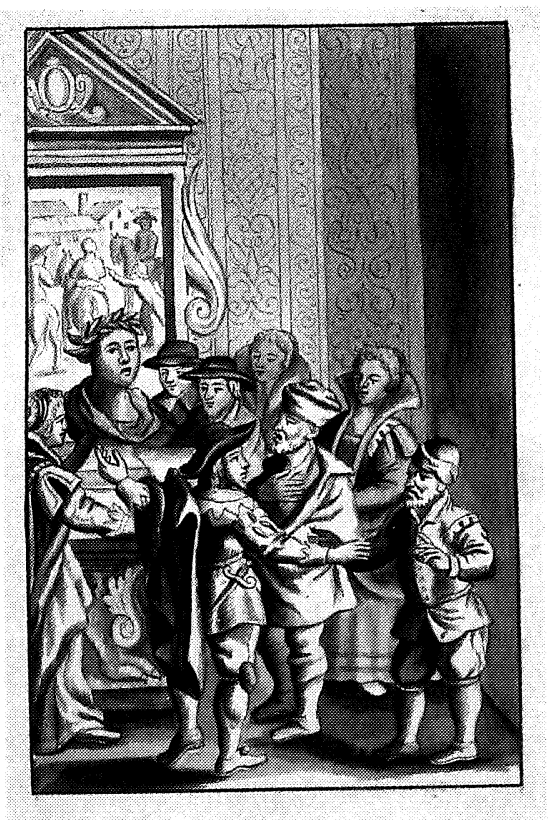

32. Aventura de la cabeza encantada (II, cap. 62) 
140 • JOSÉ MANUEL LUCÍA MEGÍAS

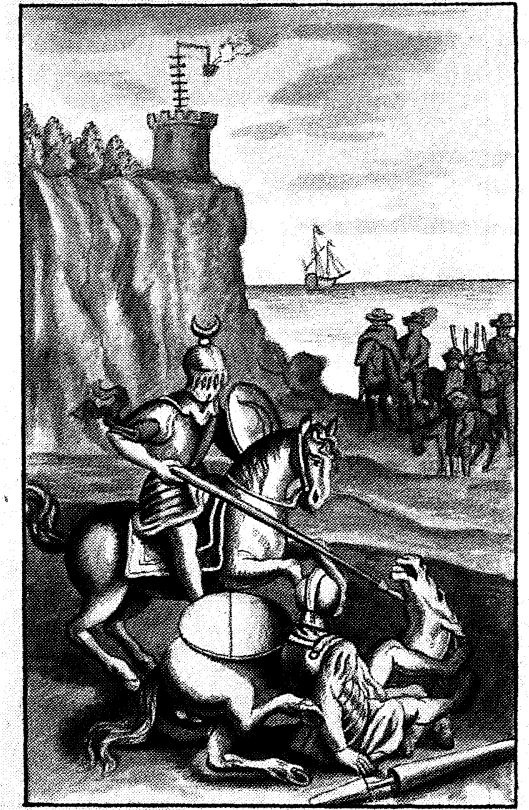

33. Don Quijote derrotado en Barcelona (II, cap. 64)

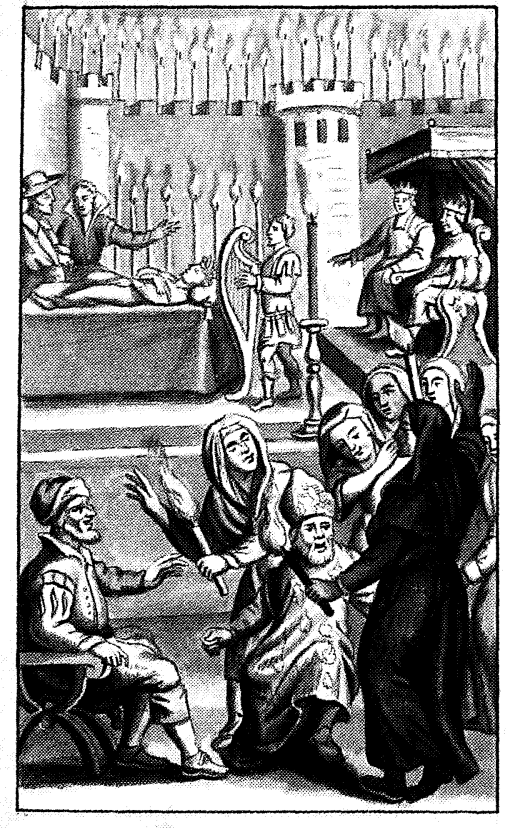

34. Encantamiento de Altisidora (II, cap. 69) 